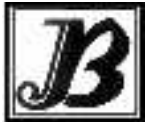

J. bio-sci. 21: 27-34, 2013

ISSN 1023-8654

http://www.banglajol.info/index.php/JBS/index

\title{
ASSESSMENT OF THE ABUNDANCE AND SPECIES COMPOSITION OF PHYTOPLANKTON OF MOIUR RIVER, KHULNA
}

\author{
Md Lifat Rahi*, Sarower-E-Mahfuj, Sk Shahinur Islam, S Saiful Islam, Wasim Sabbir \\ Fisheries and Marine Resource Technology Discipline, \\ Khulna University, Khulna-9208, Bangladesh
}

\begin{abstract}
Context: Phytoplanktonic community structure in an aquatic body embodies the energy transfer through this phase and indicates the tropic status.

Objectives: The present study was conducted to assess the phytoplankton abundance and species composition of Mouri River, Khulna, Bangladesh.

Materials and Methods: Water samples were collected from six different stations once in a week for a period of 6 months (February- July) 2010.

Results: In total 48 different species of 23 genus and 4 families were identified. Phytoplankton abundance varied from 805 to 1788 individuals/L in different stations. The highest abundance was observed for the family chlorophyceae that constituted $27-50.56 \%$ of the total phytoplankton biomass throughout the river. Highest number of phytoplankton species (22) was also recorded for the family chlorophyceae. The most diverse genus was Navicula (6). Some aspects of the water quality parameters were measured by regression analysis and significant correlations were also observed between water quality parameters and phytoplankton abundance. Water temperature, $\mathrm{pH}$, DO, Free $\mathrm{CO}_{2}$, alkalinity, hardness, calcium and magnesium showed positive correlations with total phytoplankton abundance where as transparency, TDS, TSS, sulfate phosphate and nitrite showed negative correlations.

Conclusion: In most of the cases, phytoplankton abundance and water quality parameters showed greater deviation from the optimum level. However, the results of the present experiment confirmed the polluted water of the river.
\end{abstract}

Key words: Phytoplankton, abundance, assessment, water quality.

\section{Introduction}

Phytoplankton is one of the most important biological indicators of water quality as they are important primary producers and the basis of the food chain in aquatic environment. Phytoplankton communities represent the major source of organic carbon production in larger rivers (Davies et al. 2008) and the primary oxygen source in low gradient rivers (Wehr and Descy 1998). Phytoplanktons are also responsive to excessive supplies of inorganic nutrients and may pose problems in long stretches of water bodies with eutrophication. Thus, they may also enhance water quality for humans in rivers by agricultural or industrial uses (Reynolds 2003). The species composition, abundance, distribution and diversity of phytoplankton are used to assess the biological integrity of the water body (Passy 2007). Sometimes phytoplankton develops noxious blooms, creating an offensive taste, odor and toxic conditions that may result in animal death and human illness (Chattopadhyay and Banerjee 2007).The ultimate aim of ecology is to study the interaction of organisms with their environment and the other organisms living in it (Wilson1992, Krebs 2001). Riverine ecosystems are the integral and important component of freshwater ecosystem. The knowledge of phytoplankton in the aquatic environments could be useful in predicting the movement of herbivore fishes. Many species of river

\footnotetext{
* Corresponding author E-mail: lifatrahi@gmail.com
} 
phytoplankton reproduce prolifically in rivers and achieve excess biomass levels (Sharma et al. 2007). Year to year fluctuation in plankton quality is general phenomenon in freshwater impoundment and the factors attributed to it are variation in rainfall, siltation, depth of water body, pollution and other chemical factors (Bhaumik et al. 2006). Phytoplankton communities undergo a continual succession of dominant species due to changes in growth factors, such as light, temperature and nutrients concentrations (Islam et al. 2008). Over the last few decades, there has been much interest in the processes influencing the development of phytoplankton communities, primarily in relation to some physico-chemical factors (Ariyadej et al. 2004).

The Moiur River is about $9.5 \mathrm{~km}$ long, flows at the North West side of the Khulna city and falls into the Rupsha River near Badamtala, Khulna, Bangladesh. From the very beginning of the Khulna city moderation for the civilian this river is used as the dumping ground of various municipal, industrials and domestic wastes. Under the Khulna Development project the river is controlled by established sluice gate at the opening mouth near Badamtala in 1983 to recover the lands which were under tidal action. Since then the river acts as the reservoir of wastes produced from various sources in Khulna city. There are about 18 big and small canals and drains that drain out the effluents and waste products from the whole Khulna city. The total system has been making the river polluted day by day. But the river still acts as a source of fish production and many people use this river water for their domestic uses.

There is a dearth of information on phytoplankton community of different rivers of Bangladesh and particularly there is no previous ecological investigation on the Moiur River. Considering these facts, present investigation was carried out in the Moiur River, Khulna, which is heavily polluted by sewage and industrial effluents (Sabbir et al. 2010). The objectives of the present study were to assess the species composition, abundance of phytoplankton in the Moiur River and also to determine phytoplankton abundance in relation to some physico-chemical parameters of water.

\section{Materials and Methods}

\section{Selection of the study area}

Six different stations were selected at $1.5 \mathrm{Km}$ interval. The stations were Rayar Mohal (Station-I), Shashanghat (Station-II), Gollamari bridge (Station-III), near Moulovir Dargah (station-IV), Nirala grave yard (Station-V) and Ten gate (Station-VI).

\section{Sample collection}

Samples were collected from six different stations at morning (8-9 am). Phytoplanktons were collected by $25 \mu \mathrm{m}$ mesh sized plankton net. Phytoplankton samples were then preserved with Lugol's Solution at a rate of $1 \mathrm{ml}$ per $250 \mathrm{ml}$ samples. Samples were preserved in plastic bottles.

\section{Identification of phytoplankton and counting}

Phytoplankton identification was performed according to the literature (APHA 1992, Bellinger 1992) The Sedgwick-Rafter (S-R) cell (50 mm long, $20 \mathrm{~mm}$ wide and $1 \mathrm{~mm}$ deep) was used for the counting of phytoplankton. To identify the phytoplankton, preserved samples were gently shaken to re-suspend all materials and allowed to settle for one minute. Then $1 \mathrm{ml}$ sub-sample was examined using S-R cell and a binocular microscope. The S-R cell is equally divided into 1000 fields, each having a volume of $0.001 \mathrm{ml}$. Phytoplankton counting was then performed by using the following formula:

$$
\mathrm{No} / \mathrm{ml}=\frac{\mathrm{C} \times 1000 \mathrm{~mm}^{3}}{\mathrm{~L} \times \mathrm{D} \times \mathrm{W} \times \mathrm{S}}
$$

Where, $C=$ Number of organisms counted; $\mathrm{L}=$ length of each strip (S-R cell) in $\mathrm{mm}$; $\mathrm{W}=$ Width of each strip (S-R) cell in $\mathrm{mm}$; $\mathrm{D}=$ depth of each strip (S-R cell) in $\mathrm{mm}$; and $\mathrm{S}=$ number of strips counted. 


\section{Water quality parameters}

Mercury thermometer, $\mathrm{pH}$ meter ( $\mathrm{HI}$ 98107) and Secchi-disc were used to measure water temperature, $\mathrm{pH}$ and transparency respectively. Dissolve oxygen, free $\mathrm{CO}_{2}$, alkalinity and hardness were measured by titrimetric method (Greenberg et al. 1992). Sulfate, phosphate, calcium and magnesium were determined according to the methods of Romesh and Anbu 1996). Nitrate was determined by colorimetric method. Total dissolved solids (TDS) and total suspended solids (TSS) were measured according to Ragothaman and Trivedi (2002).

\section{Results and Discussion}

\section{Species composition of phytoplankton}

In the present investigation, 4 different classes (chlorophyceae, cyanophyceae, bacillariophyceae and euglenophyceae), 23 genus and 48 species of phytoplankton were identified in the Mouri river (Table 1). Out of these identified 48 species, 22 belonged to the class chlorophyceae, 9 to bacillariophyceae, 7 to euglenophyceae and 10 to cyanophyceae. The highest number of phytoplankton species diversity was observed to be 20 in the station-4 and the lowest number was 15 in the station-1. The species Oscillatoria irriguna was found in all the 5 stations exhibiting maximum occurrence. On the other hand, Ankistrodesmus falcatus, Panorina morum, Nitzschia recta, N. denticula, Euglena viridis, Phacus acuminatus and Oscillatoria chloria were found in 4 stations and the others were least abundant; found in 1 or 2 or 3 stations. Pollution indicating species of phytoplankton were found throughout the river.

Table 1. List of identified phytoplankton species at different stations of the Moiur river.

\begin{tabular}{|c|c|c|c|c|c|c|c|}
\hline Class & Identified Species & S-1 & S-2 & S-3 & S-4 & S-5 & S-6 \\
\hline \multirow{22}{*}{ Chlorophyceae } & Ankistrodesmus falcatus & $P$ & $P$ & $P$ & - & - & $P$ \\
\hline & Chlorella vulgaris & $\mathrm{P}$ & $\mathrm{P}$ & - & - & - & - \\
\hline & Chlorococcum infusionum & $\mathrm{P}$ & - & - & $\mathrm{P}$ & - & - \\
\hline & Closterium limneticum & $\mathrm{P}$ & - & - & - & $\mathrm{P}$ & - \\
\hline & Closterium moniliferum & $\mathrm{P}$ & - & - & - & $\mathrm{P}$ & - \\
\hline & Closterium microporum & - & $\mathrm{P}$ & $\mathrm{P}$ & - & - & - \\
\hline & Closterium parvulum & - & $\mathrm{P}$ & - & - & - & - \\
\hline & Schizomeris leiblienii & - & $\mathrm{P}$ & $\mathrm{P}$ & - & - & - \\
\hline & Tetraedon incusforma & - & $\mathrm{P}$ & - & - & - & - \\
\hline & Tetraedon muticum & - & $P$ & - & - & - & $P$ \\
\hline & Thallasoria sp. & - & $\mathrm{P}$ & - & - & - & - \\
\hline & Actinastrum hantzschii & - & - & $\mathrm{P}$ & $\mathrm{P}$ & - & $\mathrm{P}$ \\
\hline & Pandorina morum & - & - & $\mathrm{P}$ & $\mathrm{P}$ & $\mathrm{P}$ & $\mathrm{P}$ \\
\hline & Scenedesmus obliqus & - & - & $P$ & - & - & - \\
\hline & Selenastrum quracile & - & - & $\mathrm{P}$ & $\mathrm{P}$ & - & - \\
\hline & Oedogonium minus & - & - & - & $\mathrm{P}$ & - & - \\
\hline & Oedogonium patulum & - & - & - & $\mathrm{P}$ & $\mathrm{P}$ & $\mathrm{P}$ \\
\hline & Cyclotella sp. & - & - & - & $\mathrm{P}$ & - & - \\
\hline & Spirogyra jaoense & - & - & - & - & $\mathrm{P}$ & - \\
\hline & Spirogyra singularis & - & - & - & - & $\mathrm{P}$ & $\mathrm{P}$ \\
\hline & Spirogyra subsalsa & - & - & - & - & $\mathrm{P}$ & $\mathrm{P}$ \\
\hline & Ulothrix zonata & - & - & - & - & - & $\mathrm{P}$ \\
\hline
\end{tabular}


Table 1. List of identified phytoplankton species at different stations of the Moiur river. (Contd.Table 1.)

\begin{tabular}{|c|c|c|c|c|c|c|c|}
\hline Class & Identified Species & S-1 & $\mathrm{S}-2$ & $\mathrm{~S}-3$ & S-4 & S-5 & $\mathrm{S}-6$ \\
\hline \multirow{9}{*}{ Bacillariophyceae } & Nitzschia ventricosa & $\mathrm{P}$ & - & - & - & - & - \\
\hline & Nitzschia recta & $P$ & $P$ & - & - & $P$ & $P$ \\
\hline & Nitzschia denticula & - & $\mathrm{P}$ & - & $\mathrm{P}$ & $\mathrm{P}$ & $\mathrm{P}$ \\
\hline & Navicula cocconeiformis & - & - & - & - & $\mathrm{P}$ & - \\
\hline & Navicula fluens & $\mathrm{P}$ & - & - & $\mathrm{P}$ & - & $\mathrm{P}$ \\
\hline & Navicula complanatula & $\mathrm{P}$ & - & - & - & $\mathrm{P}$ & - \\
\hline & Navicula simplex & - & $\mathrm{P}$ & - & $\mathrm{P}$ & - & $\mathrm{P}$ \\
\hline & Navicula cincta & - & $\mathrm{P}$ & - & - & $\mathrm{P}$ & - \\
\hline & Navicula bacilloides & - & - & - & $\mathrm{P}$ & - & - \\
\hline \multirow{7}{*}{ Euglenophyceae } & Euglena viridis & $\mathrm{P}$ & $\mathrm{P}$ & $\mathrm{P}$ & $\mathrm{P}$ & - & - \\
\hline & Euglena acus & $\mathrm{P}$ & $P$ & - & - & - & - \\
\hline & Euglena oestellata & - & $\mathrm{P}$ & $\mathrm{P}$ & $\mathrm{P}$ & - & - \\
\hline & Euglena stellata & - & - & $\mathrm{P}$ & $\mathrm{P}$ & - & - \\
\hline & Euglena vulgaris & - & - & - & - & $\mathrm{P}$ & - \\
\hline & Phacus acuminatus & $\mathrm{P}$ & $\mathrm{P}$ & $\mathrm{P}$ & $\mathrm{P}$ & - & - \\
\hline & Phacus curvicula & - & - & - & $\mathrm{P}$ & $\mathrm{P}$ & - \\
\hline \multirow{10}{*}{ Cyanophyceae } & Oscillatoria chlorina & $\mathrm{P}$ & - & $\mathrm{P}$ & $\mathrm{P}$ & - & $\mathrm{P}$ \\
\hline & Oscillatoria irrigua & $\mathrm{P}$ & $\mathrm{P}$ & $\mathrm{P}$ & $\mathrm{P}$ & - & $\mathrm{P}$ \\
\hline & Oscillatoria sancta & $\mathrm{P}$ & $\mathrm{P}$ & - & - & - & - \\
\hline & Oscillatoria obscura & - & - & $\mathrm{P}$ & - & - & - \\
\hline & Microcystis elabens & - & - & $P$ & - & $P$ & - \\
\hline & Microcystis protocystis & - & - & $\mathrm{P}$ & $\mathrm{P}$ & - & $\mathrm{P}$ \\
\hline & Spirulina major & - & - & $\mathrm{P}$ & $\mathrm{P}$ & - & $\mathrm{P}$ \\
\hline & Spirulina susala & - & - & - & - & $\mathrm{P}$ & - \\
\hline & Chrococcous minutes & - & - & - & - & $\mathrm{P}$ & - \\
\hline & Chrococcous tenax & - & - & - & - & - & $P$ \\
\hline
\end{tabular}

There were 135 species and 7 divisions of phytoplankton determined from the Banglang reservoir (Ariyadej et al. 2004). In the Okpoka creek, Wehr and Descy (1998) identified 7 families, 61 genus and 112 species of phytoplankton. Chattopadhyay and Banerjee (2007) Identified 43 species, 7 genus and 4 families in a small freshwater lake where cyanophyceae was the dominant. Onyema (2007) Identified 48 species from 26 genera and 3 classes in a polluted estuarine creek and Chindah (1998) identified 50 species in a municipal waste water treatment system where as Jahangir et al. (2000) identified 205 species of phytoplankton from an ecologically balanced and productive river. Thus, the results of the present experiment confirmed the narrower species composition of phytoplankton in the Moiur river.

Hosetti (1987) reported that abundance of Chlorella, Microcystis and Scenedesmus may be considered as indicators of organic pollution. However, it is also reported that Euglena and Oscillatoria could also be reliable indicators of eutrophication (Hosetti and Kumar 2002). As all of the pollution indicating phytoplankton are available throughout the river and results of the present study also support the study of 23 and 18; indicating polluted water of the river. 


\section{Phytoplankton abundance}

The mean total phytoplankton abundance in different stations of the Moiur River has been presented in Fig.1. In different stations the phytoplankton abundances were found to be $820 \pm 13.2,844 \pm 13.52,985 \pm 18.02$, $1175 \pm 47,1439 \pm 80.5$ and $1696 \pm 82.14$ individuals/ liter respectively. The range of phytoplankton abundance was varied from 805 to 1788 individuals/ liter in different stations. The group wise distributions of phytoplankton at different stations have also been presented in Table 2. Chlorophyceae was the most dominant group throughout the river constituting $27 \%$ to $50.56 \%$ of the total phytoplankton biomass. On the other hand euglenophyceae was the lowest abundant group constituting $5.89 \%$ to $35.05 \%$ of the total plankton biomass at different stations in the river.

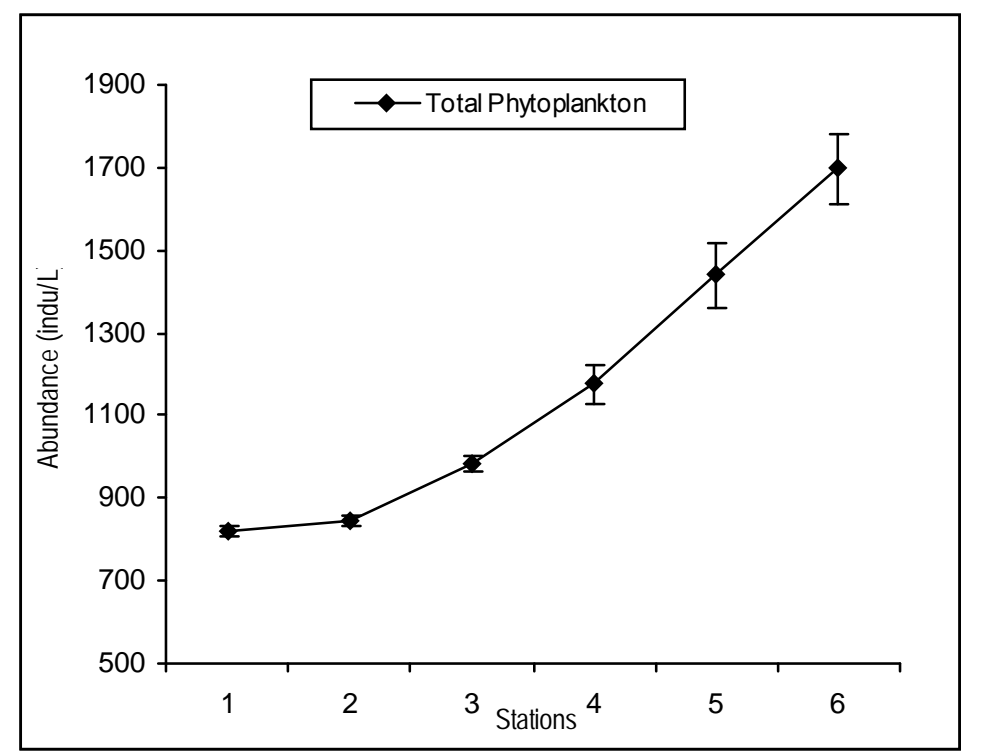

Fig. 1. Total phytoplankton abundance at different stations of the Mouri river.

Table 2. Group wise distribution of phytoplankton at different stations of the Mouri river.

\begin{tabular}{|c|c|c|c|c|c|c|}
\hline \multirow{2}{*}{$\begin{array}{c}\text { Groups } \\
\text { (individuals IL) }\end{array}$} & \multicolumn{7}{|c|}{ Stations } \\
\cline { 2 - 7 } & Station- I & Station- II & Station- III & Station- IV & Station- V & Station- VI \\
\hline Chlorophyceae & 225 & 240 & 350 & 580 & 565 & 766 \\
\hline$\%$ of Total & $27 \%$ & $28 \%$ & $35.51 \%$ & $50.56 \%$ & $41.15 \%$ & $44.47 \%$ \\
\hline Bacillariophyceae & 230 & 152 & - & 195 & 380 & 640 \\
\hline$\%$ of Total & $27.90 \%$ & $18.28 \%$ & - & $16.66 \%$ & $25.96 \%$ & $37.38 \%$ \\
\hline Euglenophyceae & 55 & 190 & 345 & 150 & 300 & 100 \\
\hline$\%$ of Total & $6.18 \%$ & $22.14 \%$ & $35.05 \%$ & $12.38 \%$ & $20.77 \%$ & $5.89 \%$ \\
\hline Cyanophyceae & 270 & 280 & 290 & 250 & 184 & 180 \\
\hline$\%$ of Total & $32.72 \%$ & $33.17 \%$ & $29.89 \%$ & $12.48 \%$ & $13.64 \%$ & $10.62 \%$ \\
\hline
\end{tabular}


Ariyadej et al. (2004) reported that chlorophyceae was the most dominant group (50\% of total plankton) in freshwater reservoir and also reported the phytoplankton abundance as $2.1 \times 10^{9}$ cells $^{-3}$. In freshwater creek ecosystem, Davies et al. (2008) observed bacillariophyceae (diatom) as the dominant group (35.2\% of total phytoplankton) and total phytoplankton abundance as 7166 individuals/l. Onyema (2007) observed lower load of phytoplankton in a polluted estuarine creek ranging 726-1751 units/l where as in a productive river Jahangir et al. (2000) observed very suitable amount of phytoplankton abundance for aquatic life ranging 3652-5459 individuals/l in different seasons. Bhaumik et al. (2006) reported phytoplankton abundance as 4684-4726 indv./l, 4984-5460 indv./l and 2134-3380 indv./l during winter, summer and monsoon seasons in a productive beel. Chindah et al. (2007) also reported lower load of phytoplankton in municipal waste water treatment system.

Phytoplankton abundance in the present study always showed greater deviations from the abundance of productive water bodies but supports the findings of the polluted water. Thus, the results of the present study confirmed that the abundance of phytoplankton is very low in the Moiur river. The lower phytoplankton abundance was due to the excessive load of pollutants within the river that come from municipal, urban and industrial wastage and effluents.

\section{Phytoplankton abundance in relation to some physico-chemical parameters}

Some aspects of physico-chemical parameters of the river were measured but varied from place to place and month to month. Significant correlations were observed between phytoplankton abundance and different physico-chemical parameters (Table 3). The measured parameters showed a great deviation from the optimum or standard levels in almost all cases. The parameters tend to be better towards the downstream but in upstream areas water quality was very poor. The poor water quality in upstream areas of the river was due to the higher dumping rate in these areas. As the water moves, the pollutants tend to decrease toward the downstream and that's why phytoplankton abundance was found to be higher in downstream areas (stations-4, 5 and 6). During the present investigation temperature, $\mathrm{pH}$, dissolved oxygen (DO), free $\mathrm{CO}_{2}$, alkalinity, hardness, calcium and magnesium showed positive correlation with total phytoplankton abundance. But transparency, total suspended solids (TSS), total dissolved solids (TDS), $\mathrm{SO}_{4}, \mathrm{PO}_{4}$ and nitrate showed negative correlations with phytoplankton abundance.

Table 3. ' $r$ ' values for phytoplankton abundance with some physico-chemical parameters.

\begin{tabular}{|c|c|c|c|c|c|}
\hline \multirow{2}{*}{ Parameters } & \multicolumn{4}{|c|}{ Phytoplankton } \\
\cline { 2 - 6 } & Chlorophyceae & Cyanophyceae & Euglenophyceae & Bacillariophyceae & Total \\
\cline { 2 - 6 } & $\mathbf{r}$ & $\mathbf{r}$ & $\mathbf{r}$ & $\mathbf{r}$ & $\mathbf{r}$ \\
\hline Temperature & 0.9477 & 0.7952 & -0.6307 & 0.6861 & 0.9295 \\
\hline $\mathrm{pH}$ & 0.5354 & 0.9683 & -0.6184 & 0.3370 & 0.4042 \\
\hline Transparency & -0.67 & 0.553 & 0.7659 & -0.7115 & -0.6589 \\
\hline TSS & -0.5582 & -0.1074 & 0.7364 & -0.6893 & -0.5706 \\
\hline TDS & -0.1501 & 0.2498 & 0.4854 & -0.3958 & -0.1649 \\
\hline DO & 0.8962 & 0.9683 & -0.5203 & 0.454 & 0.7981 \\
\hline CO, & 0.5059 & 0.8073 & -0.4926 & 0.5969 & 0.5574 \\
\hline Alkalinity & 0.5191 & 0.9683 & -0.0287 & 0.205 & 0.5176 \\
\hline Hardness & 0.4223 & 0.9967 & -0.0376 & 0.2332 & 0.4458 \\
\hline Sulfate & -0.2177 & -0.9683 & 0.4097 & -0.7544 & -0.4507 \\
\hline Phosphate & -0.3155 & 0.885 & 0.3348 & -0.7567 & -0.5562 \\
\hline Calcium & 0.875 & 0.548 & 0.599 & -0.521 & 0.325 \\
\hline Magnesium & 0.458 & 0.564 & 0.589 & -0.325 & 0.569 \\
\hline Nitrate & -0.7713 & 0.2248 & 0.6339 & -0.4321 & -0.6511 \\
\hline
\end{tabular}


Ariyadej et al. (2004) observed significant correlation of phytoplankton with several water quality parameters viz. temperature, $\mathrm{pH}, \mathrm{DO}$, transparency, nutrients and conductivity. Such significant correlations of phytoplankton abundance with the physico-chemicals are also observed by some other authors as well (Uye and Shimazu 1997, Chindah 1998, Jahangir et al. 2000, Back et al. 2006, Wehr and Descy 1998).

Onyema (2007) observed the highest abundance of phytoplankton in a polluted lake during rainy season due to the lower load of pollutants and also observed lower $\mathrm{O}_{2}$ content (3.8-4.2 $\left.\mathrm{mgl}^{-1}\right)$, higher $\mathrm{pH}(8-9)$, higher level of $\mathrm{PO}_{4}$ and very high biological oxygen demand $\left(>18 \mathrm{mgl}^{-1}\right)$. All of the measured water quality parameters in the present study showed sharp deviation from required level for aquatic organisms. The water of the river is almost unsuitable for fish and other important nektonic species.

\section{Conclusion}

The phytoplankton abundance, species composition and some water quality parameters of the Moiur river were determined successfully in the present study. This river acts as the main dumping site of wastage of Khulna city. Many people live on the bank of this river and use the polluted water for various purposes. Thus, proper treatment system must be used to purify the water while dumping. Proper steps should also be taken to save the biodiversity of the river and to make the river water suitable for aquatic organism as well as usable for various domestic, industrial and other activities.

\section{References}

APHA (American Public Health Association) 1992. Standard Methods for the Examination of Water and Wastewater. American Public Health Association, Washington D.C.

Ariyadej C, Tansakul R, Tansakul P, Angsupanich S. 2004. Phytoplankton diversity and its relationship to the physicochemical environment in the Banglang Reservoir of Yala Province. Song J Sci Tech 26(5), 595-607.

Back S, Kaupilla P,Kangas P, Ruuskanen A, Westberg V, Perus J, Raike A. 2006. A biological monitoring program for the coastal waters of Finland according to the EU water framework directive. Environ Res Eng Man 38(4), 6-11.

Bellinger EG. 1992. A Key to Common Algae: Freshwater, Estuarine and Some Coastal Species. Institute of Water and Environmental Management, London, UK, 138 pp.

Bhaumik U, Das P, Paria T. 2006. Impact of Plankton structure on Primary Productivity in Two Beels of west Bengal, India. Ban J Fish Res 10(1), 01-11.

Chattopadhyay C, Banerjee TC. 2007. Temporal changes in environmental characteristics and diversity of net phytoplankton in a freshwater lake. Turk J Bot 31, 287-296.

Chindah AC, Braide SA, Amakiri J, Izindu E. 2007. Succession of phytoplankton in a municipal waste water treatment system under sunlight. Rev UDO Agri 7(1), 258-273.

Chindah AC. 1998. The effects of industrial activities on the periphyton community at the upper reaches of Niger delta, Nigeria. Wat Reso 32(4), 1137-1143. http://dx.doi.org/10.1016/S0043-1354(97)00296-0

Davies OA, Abolude DS, Ugwumba AAA. 2008. Phytoplankton of the lower reaches of Okpoka creek, Port Harcourt, Nigaria. J Fish Int 3(3), 83-90.

Greenberg AE, Clesceri LS, Eaton AD. 1992. Standard method for the examination of water and waste water, $18^{\text {th }}$ edition, American Public Health Association, New York.

Hosetti BB, Kumar A. 2002. A text book of applied aquatic biology, $1^{\text {st }}$ edition, Daya publishing house, New Delhi, India. pp. 41-65.

Hosetti BB. 1987. Studies on the use of some important groups of microbes in the treatment of waste waters, Dharwad. Department of Environmental Science, Karnataka University, India. (Ph.D. thesis). 
Islam MS, Rahaman SMB, Hasanuzzaman AFM, Sarower MG, Sayeed MAB, Sabbir W. 2008. Qualitative and quantitative variation in plankton communities between mono and poly-culture systems in Khulna, Bangladesh. Khu Univ Stu 9(1), 111-116.

Jahangir TM, Khuhawar MY, Leghari SM, Baloach WA, Leghari A. 2000. Some studies on water quality and biological life at Kinjhar and Halegi lakes of Thatta, Sindh, Pakistan. Pak J Biol Sci 3(11), 1965-1972. http://dx.doi.org/10.3923/pjbs.2000.1965.1972

Krebs CJ. 2001. Ecology. $5^{\text {th }}$ edition, Addison-Wesley, San Fransisco, USA.

Onyema IC. 2007. The phytoplankton composition, abundance and temporal variation of a polluted estuarine creek in Lagos, Nigeria. Turk J Fish Aqua Sci 7, 89-96.

Passy SI. 2007. Diatom ecological guilds display distinct and predictable behavior along nutrient and disturbance gradients in running waters. Aqua Bota 86, 171-178. http://dx.doi.org/10.1016/j.aquabot.2006.09.018

Ragothaman G, Trivedi RK. 2002. A text book of aquatic ecology. $1^{\text {st }}$ edition, Agrobios Publishing Co., New Delhi, India.

Reynolds CS. 2006. The ecology of phytoplankton, $1^{\text {st }}$ edition, New York: Cambridge.

Romesh R, Anbu M. 1996. Chemical method for the environmental analysis: water and sediment, Macmillan Ltd., India.

Sabbir W, Abdullah-Al-Masud M, Islam SS, Rahman MA, Islam MR, Rahi ML. 2010. Some Aspects of the Water Quality Parameters of the Mouri River: An Attempt to Estimate Pollution Status. Bangladesh Research Publications Journal 4(1), 95-102.

Sharma A, Sharma RC, Anthwal A. 2007. Monitoring Phytoplanktonic diversity in the hill stream Chandrabhaga of Garwal Himalaya. Lif Sci J. 4(1), 80-84.

Uye T, Shimazu K. 1997. Geographical and seasonal variations in abundance, biomass and estimated production rates of meso and macro-zooplankton in the inland sea of Japan, J Ocean 53, 529-538.

WehrJ D, Descy JP. 1998. Use of phytoplankton in large river management. J Phyc 34(5), 741-749. http://dx.doi.org/10.1046/j.1529-8817.1998.340741.x

Wilson EO. 1992. The diversity of life. Penguin Books, London, UK, 406 pp. 